Vol. 8, No. 3, 2020, pp. 234-237

DOI: https://doi.org/10.29210/148200

Contents lists available at Jurnal IICET

Jurnal Konseling dan Pendidikan

ISSN: 2337-6740 (Print) ISSN: 2337-6880 (Electronic)

Journal homepage: http://jurnal.konselingindonesia.com

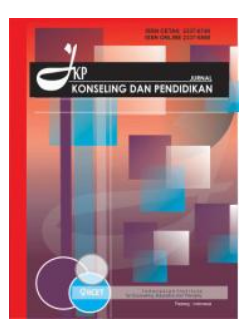

\title{
Counseling service in overcoming faith and morality issues for inmates child
}

\author{
Fadila Fadila $^{1^{*}}$, Beni Azwar $^{2}$, Hartini $^{3}$ \\ ${ }^{123}$ Institut Agama Islam Negri Curup
}

\begin{tabular}{l}
\hline Article Info \\
\hline Article history: \\
Received Oct 27th, 2020 \\
Revised Nov 30th, 2020 \\
Accepted Des 28th, 2020
\end{tabular}

\section{Keyword:}

Inmates child

Religion

Values and Moral

\begin{abstract}
According to the Directorate General of Corrections, more than 7,000 children perpetrate criminal offenses on a yearly basis. To reduce this crime rate, it is of great necessity to reinforce Religion, values, and morals (RNM) through appropriate counseling services to Inmates child at the Rejang Lebong Class II A Curup Correctional Institution. The solution to the problem in this study is first, improving the condition of religion, the values, and morals of the child. Second, the type of counseling assignment in terms of Religion, Values, and Morals of the children faced with the law. Third, the condition of religion, the values and morals of the children who became upright after counseling services is given. This research is based on the grounded theory which has to do with building a theory through inductive studies. His observations are illustrated by the results of the $87 \%$ of inmates child themed test problem in ANM. He was given personal guidance for the development of religious life in the areas of information services, content mastery services, group guidance services, and individual counseling. At the test post, there was a decrease of $43 \%$ in the inmates child ANM problems.
\end{abstract}

\section{Corresponding Author:}

Fadila Fadila,

Email: unifadila@yahoo.co.id

\section{Introduction}

Children are gifts and a mandates from Allah SWT to every parent. Various efforts are made by parents to see their children grow and develop as expected. In most cases, their expectations are not brought into reality, probably because of ineffective parenting system or lack of supervision by parents. When this happens, some children engage in actions that are against the rules of society. Criminal acts committed by children (juvenile delinquency) are increasing in line with several motives on a daily basis.

According to the data obtained from the Directorate General of Corrections, every year more than 7,000 children perpetrate criminal acts that have proceeded them to the judiciary. According to Romli Atmasasmita in Wagiati Soetodjo, several factors motivate children to engage in delinquency and criminal activities. These factors are generally grouped into intrinsic and extrinsic motivation. Intrinsic factors include intelligence, age, sex and position of children in the family, while extrinsic factors have to do with family issues, education and parenting, peer influence and mass media (Soetodjo, Wagiati, 2006). These factors have the tendencies to instigate children against the laws of society. Article 1 paragraph (2) of Law No. 11 of 2012 concerning the Child Criminal Justice System, relates to children who are found guilty before the law. It states that: "Children who act against the Law becomes victims of criminal acts.

Meanwhile, we have to understand the term children according to Article 1 point 1 of Act Number 23 of 2002 concerning Child Protection: "A child is someone who is not 18 (eighteen) years old, including those in 
the womb". While base on Article 1 paragraph (3) Law No. 11 of 2012 concerning the Child Criminal Justice System also describes children that act against the law, it states that: "Children found guilty before the Law, are those who are 12 (twelve) years old, but not yet 18 (eighteen) years old, suspected of committing a criminal act ".

The Curup Confinement Class II data shows that they have a total of 560 inmates. Those at the age of 18 years are 40, while about 75 officers and children staffs are 275 . The observation from the research shows that children who act against the rules of the society do not meet up to societal standards.

According to the legislation stipulated in article 90 paragraph 1 of RI Law No. 11 concerning the juvenile justice system: "Child victims and child witnesses have the right to (1) medical rehabilitation and social rehabilitation both within the institution and outside institution. (2) Guarantee of safety, both physical, mental and social (3) ease in obtaining information about the development of cases ". Hence, researchers are interested in evaluating counseling services relating to the problem of Religious Values and Morals for inmates child in the Curup penitentiary class II A in Rejang Lebong.

\section{Research objectives}

This research aims to discover first, the condition of the Value and Moral Religion of the Child guilty of before the law. Secondly, the most important counseling services in dealing with the problems of religion, values, and morality of children that are faced with the law. Third, the condition of Religion, Values, and Morals of the Children after counseling services have been administered.

\section{Formulation of the problem}

1) What is the condition of the Value, Moral and Religion of the Child against the law; 2) Counseling services in dealing with the problems of Religion, Values, and Morals of children dealing with the law; 3) How is the condition of Religion, Values, and Morals of Children after the counseling services?

\section{Study of theory}

Correctional Institutions are sub-criminal justice system institution that have a strategic role of implementation of criminal imprisonment as well as fostering places for inmates. As mandated in Law No. 12 of 1995 concerning correctional services " it is a place to carry out coaching inmates, students correction, and clients (prisoners) correction." (Amin Dwi Cahyo, 2016). In line with the definition above, the writer can conclude that Penitentiary is a place to foster, protect, guide, direct the inmates to improve themselves and not repeat the mistakes so that they can become better human beings and be accepted back in the community, actively playing a role in development and living naturally as a citizen.

Coaching involves "activities that enhance the quality of devotion to God Almighty, intellectual, attitudes and behavior, professional, physical and spiritual health of Prisoners and Correctional Students "According to the Indonesian dictionary, the term coaching means" the efforts, actions, and activities performed efficiently and effectively to obtain better results. "(Perpu Number 31 of 1999). Coaching is "an activity that seeks to make someone with a bad behavior good, with a personal approach while putting conscious mechanisms in place to know the causes of behavior that are not good." (Sarwono, Sarlito Wirawan, 2001). According to Article 2 of Law No. 12 of 1995, the purpose of coaching is, "Penitentiary systems are organized to enable the inmates to become fully human, aware of mistakes, improve themselves and not repeat criminal acts so that they can be accepted again by the community, can actively play a role in development and can live naturally as a good and responsible citizens ". (Erina Suhestia Ningtyas)

To reduce the level of crime committed by adolescents, especially underage children, it is necessary to cultivate religious values and strong counseling service for children in the Curup Correctional Institution Class II A in Rejang Lebong.

The implementation of counseling services in Indonesia has helped to reduce the rate of crimes. This evolution has developed since the emergence of various misconceptions about guidance and counseling in the field. There is a wrong notion that the implementation of guidance and counseling was seen to be a process that was not based on the educational process. Hence in the past years, counseling services did not have substantial effects on the crime rate. This modern reformation came with some better characteristics and its objects that the implementation of guidance and counseling services cannot be carried out by anyone with any educational background because the implementation of guidance and counseling is supposed to be conducted by individuals who are academically prepared to work professionally in the field of counseling. Carl R. Rogers (1954) explained that counseling is a process of individual relationships with therapists that 
reviews experience integrated into oneself that will be changed. The therapist in question is called a counselor, and the individual in question is a client or counselee. The relationship process takes place in a professional environment, it begins and is maintained as a means of facilitating changes in client or counselee behavior. Harold Pepinsky and Pauline Pepinsky, (1954). The client has to interpret facts relating to choices, plans, or adjustments that the counselee needs.G lenn E. Smith, (1955). This gives room to clients or counselees who are troubled by problems to be given effective solutions to their various challenges. Gilton E. Hahnand Malcolm S. MacLean, (1955). In the process of personal interaction between the counselor and the client, a variety of information will be provided to stimulate the client to develop behaviors that allow clients to deal more effectively with themselves and their environment Edwin C. Lewis. (1970) This will make the individuals more aware of themselves and the ways they respond to environmental factors. The process of counseling further helps individuals to build some personal behavior, develop and clarify goals and values. Donald H. Bobcher, (1974)

Activities will be carried out in accordance with the problems and needs encountered in the field to provide the best guidance services. There are Six areas of guidance, and they include Personal guidance, Social guidance, Tutoring, Career guidance, Family life development guidance, Field guidance for the development of religious life. Children facing the law are also provided with nine services, including Orientation Services, Information Services, Placement and Distribution Services, Content Mastery Services, Individual Counseling Services, Group Guidance Services, Group Counseling Services, Consultation Services, and Mediation Services.

\section{Method}

This research used the grounded theory. It was seen by Earl Babie as qualitative research that aims to build theory through inductive investigation. This approach places more significance on research activities that relate directly to various data such as observation; in-depth interview or in-depth interview. Earl Babie defines grounded theory as: "... an inductive approach to the study of social life, by constant comparison of unfolding observations. This differs greatly from hypothesis testing, which is tested through observations. (Earl Babie. Belmont: Wadsworth, 2011). While the follow-up of the results of research using grounded theory was obtained by performing an experimental approach to improve the knowledge, understanding, skills, and attitudes (WPKNS) of inmates child in Curup Correctional Institution Class II A, Rejang Lebong. The sequence and procedure for implementing this research includes: First, the significant problems to be investigated; second, the selection of subjects that are sufficient to be treated which is included in the experimental group; Third is the development of instruments; Fourth selection of research designs; Fifth, procedure execution; Sixth, perform data analysis; Seventh, formulate conclusions.

\section{Result and Discussion}

Child's Religion and Moral Condition influenced their behavior in regard to the law. The results are illustrated from the data obtained from the pree test for Children Against the Law experiencing 87\% of problems in the Moal Value Religion. From the interviews, some children do not know the pillars of Faith and the pillars of Islam while some are not able to read the Koran. Most children do not pray and fast because they do not know the prayer readings. This will influence the child and make he/she engage in sex abuse, theft, and drugs activities.

From the results of the posttest, counseling services were conducted to deal with the problems of Religion, Values, and Morals of children facing the law. Then personal guidance was also administered by the ministry of guidance for the development of religious life.

Efforts to improve spirituality and knowledge of the Islam religion and faith in Allah SWT, indeed, must be improved to help the Aqeedah and Morals for inmates child. This is to help increase their faith and knowledge of Islam, to realize their mistakes and avoid repetition. The materials used in performing counseling services must be related to Aqidah, Sharia and Morals.

The Conditions of Religion, Values, and Morals of Children given counseling services was changed for the better. In the posttest, there was a decline. We discovered that $43 \%$ of the problems of the value and moral religion of children were resolved. The child prayed five times by first studying his reading. They now know the pillars of faith and the pillars of Islam. Children have learned to read the Qur'an and other Islamic laws. 


\section{Conclusion}

Many children having issues with the law experience problems in Value and Moral Religion as illustrated by the results of the inmates child test experiencing. $87 \%$ of the children had problems with Value and Moral Religion. They were given counseling services and personal guidance. This helped to develop their religious life. In information services, content mastery services, group guidance services and individual counseling were enhanced with the Aqeedah, Sharia, and morality. According to the results of the test post data, there was a decline of about $43 \%$ religious problems, values and morals.

\section{References}

Amin Dwi Cahyo, "Manajemen Pembinaan Agama Islam Pada Narapidana Lembaga Pemasyarakatan klas II A Wirogunan Yogjakarta.'Tesis.program Pascasarjana UIN Sunan Kalijaga Yogyakarta, 2016

Babie. Earl,2011, The Basics of Social Research, Belmont: Wadsworth.

CarlR.Rogers," 1954. 'Client-Centered' Psychotherapy," ScientificAmerican, 187 p.70

Donald H.Blocher, 1974. Developmental Counseling,2nd ed.New York: Ronald Press,, p. 7

Edwin C. Lewis. 1970, ThePsychologyofCounselingNew York: Holt, Rinehart andW"msron, p.10.

Erina Suhestia Ningtyas, dkk., "Pelaksanaan Program Pembinaan Narapidana Pada Lembaga Pemasyarakatan Dalam Rangka Pengembangan Sumber Daya Manusia. ”Jurnal Administrasi Publik (Jap), Vol. 1, No. 6

Glenn E.Smith, 1955.CounselingintheSecondarySchool, New York: Macmillan, p. 156.

Harold Pepinsky and Pauline Pepinsky, 1954. CounselingTheoryand Practice, New York.:Ronald Press, p.3.

Keputusan Presiden Nomor 36 Tahun 1990 Tentang Konvensi Hak Anak.

Milton E. Hahnand Malcolm S. MacLean, 1955.CounselingPsychology, New York: McGraw-Hill BookCo.,p. 6

Marlina, 2012, Peradilan Pidana Anak di Indonesia Pengembangan Konsep Diversi dan Restorative Justice, PT Refika Aditama, Bandung.

Mulyadi, Lilik, 2005, Pengadilan Anak di Indonesia Teori, Praktik dan Permasalahannya di Indonesia, Mandar Maju, Bandung.

Nashriana, S.H.,M.Hum. 2011. Perlindungan Hukum Pidana Bagi Anak di Indonesia. Jakarta: Rajawali Pers.

Peraturan Pemerintah Republik Indonesia Nomor 31 Tahun 1999 Tentang Pembinaan Dan Pembimbingan Warga Binaan Pemasyarakatan Pasal 1 Ayat 1

Prakoso Abintoro. 2013. Pembaruan Sistem Peradilan Pidana Anak. Yogyakarta: Laksabang Grafika.

Pramukti, Angger Sigit dan Primaharsya, Fuady, 2015, Sistem Peradilan Pidana Anak, Pustaka Yustisia, Yogyakarta.

Prinst, Darwan, 2003, Hukum Anak Indonesia, Citra Aditya Bhakti, Bandung.

Soetodjo, Wagiati, 2006. Hukum Pidana Anak. Bandung, PT. Refika Aditama.

Sundayana, Wachyu. (2014). Pembelajaran Berbasis Tema. Panduan Guru dalam Mengembankan Pembelajaran Terpadu. Jakarta: Erlangga.

Supramono, Gatot, 2007, Hukum Acara Pengadilan Anak, Djambatan, Jakarta.

Suyanto, Bagong. 2013. Masalah Sosial Anak. Jakarta: Kencana

Soetodjo, Wagiati, 2006. Hukum Pidana Anak. Bandung, PT. Refika Aditama.

Sarwono,Sarlito Wirawan,2001.Pengantar Psikologi Sosial, Jakarta: Rineka Cipta.

Wita Sembiring, N. Efektivitas Pembinaan Narapidana Anak Oleh Lembaga Pemasyarakatan Anak Klas IIA Tanjung Gusta Medan.

Undang-undang Nomor 8 Tahun 1981 Tentang Kitab Undang-undang Hukum Acara Pidana (KUHAP).

Undang-undang Nomor 3 Tahun 1997 Tentang Pengadilan Anak.

Undang-undang Nomor 39 Tahun 1999 Tentang Hak Asasi Manusia.

Undang-undang Nomor 11 Tahun 2012 Tentang Sistem Peradilan Anak.

Undang-undang Nomor 35 Tahun 2014 Tentang Perubahan atas Undang-undang Nomor 23 Tahun 2002 Tentang Perlindungan Anak. 